Article

\title{
Kinetika Slow Release Pupuk Urea Berlapis Chitosan Termodifikasi
}

\author{
YC Danarto*, Anggita Nugrahey, Sela Murni Noviani \\ Program Studi Teknik Kimia Fakultas Teknik Universitas Sebelas Maret Jalan Ir. Sutami No.36A, Surakarta, \\ 57126, Indonesia \\ E-mail: yc.danarto@gmail.com (Corresponding author)
}

\begin{abstract}
During this time, the use of urea is not efficient, because about $40-70 \%$ of nitrogen in the fertilizer is not absorbed by plants. In order to increase the effectivity of nitrogen release in urea fertilizer, it needs to be coated with modified chitosan as slow releasing agent to form a hydrogel material by forming a cross linking with glutaraldehyde cross-linker.The aims of this research is to study the mechanism and the appropriate kinetic model of nitrogen release in slow releasing fertilizer of modified chitosan. This research was conducted by analyzing the ability of bio-hydrogel by calculating the percentage of swelling ratio and water retention of hydrogel and the nitrogen release in slow releasing fertilizer both in the soil and water. The experiments were conducted by varying the amount of urea used which 30 gram, 40 gram, 50 gram, 60 gram and 70 gram of urea fertilizer. The The release profile is then plotted on several models of diffusion kinetic such as zero order, first order, higuchi and korsmeyer peppas. The appropriate model of diffusion kinetic is chosen by the largest correction factor (R2).The results showed that nitrogen release of the slow releasing fertilizer in the soil with $50 \%$ urea content and the water followed korsmeyer peppas model with fickian mechanism. Nitrogen release in the soil with urea content of $30 \%, 40 \%, 60 \%$, and $70 \%$ followed the korsmeyer peppas model with nonfickian mechanism.
\end{abstract}

Keywords: Chitosan, Slow Release Fertilizer, Kinetics

EQUILIBRIUM Volume 16 No.2 Juli 2017

Online at http:/ / equilibrium.ft.uns.ac.id 


\section{Pendahuluan}

Sebagai negara agraris, Indonesia membutuhkan pupuk kimia dalam jumlah yang sangat besar, salah satunya pupuk urea yang merupakan penyedia unsur nitrogen terbesar diantara pupuk kimia yang laindalam jumlah yang sangat besar. Pada tahun 2016 kebutuhan unsur hara untuk pupuk mencapai 5 juta ton unsur nitrogen yang disediakan oleh pupuk urea (APPI,2017). Namun, besarnya kebutuhan pemakaian pupuk urea tidak diimbangi dengan efisiensinya, karena sebanyak 40-70\% unsur nitrogen dalam pupuk tidak terserap tenaman(Corradini et al, 2010).Tidak terserapnya unsur nitrogen pada pupuk urea dapat diatasi dengan membentuk pupuk tersebut menjadi suatu material berbasis hidrogel. Material tersebut akan mengatur jumlah unsur nitrogen yang keluar untuk diserap tanaman. Pada penelitian ini digunakan chitosan dengan campuran $\mathrm{Na}$-Alginat sebagai bahan pelapis pupuk urea.

Chitosan merupakan salah satu material yang potensial untuk digunakan sebagai campuran untuk membentuk material berbasis hidrogel karena bersifat hidrofilik yang mampu menahan air yang menyebabkan unsur nitrogen terlepas dari pupuk. Selain chitosan, pada penelitian ini digunakan juga NaAlginat yang mampu menghambat pelepasan suspensi dalam air sebagai campuran pelapis pupuk urea.Tujuan dari penelitian ini adalah mempelajari pengaruh waktu terhadap jumlah unsur nitrogen yang terlepas dari pupuk urea, mempelajari mekanisme pelepasan unsur nitrogen pada pupuk urea berbasis chitosan hidrogel di dalam tanah maupun di dalam airdan untuk mengetahui model kinetika yang sesuai untuk mendeskripsikan peristiwa pelepasan pupuk urea.

\section{Metode Penelitian}

\section{Pembuatan pupuk urea chitosan termodifiikasi}

Pupuk Urea ( 30g, 40g, 50g, 60g, dan 70g ) dilarutkan ke dalam Na Alginat 2\%, diaduk hingga larut. Kemudian Larutan tersebut diteteskan menggunakan pipet tetes ke dalam $\mathrm{CaCl} 2$ 1\% hingga terbentuk butiran butiran gel. Kemudian butiran tersebut dipindahkan ke dalam larutan chitosan 1\%. Butiran pupuk yang sudah terlapisi chitosan dimasukkan ke dalam glutaraldehid 1\%, diaduk hingga 30 menit. Pupuk urea berlapis tersebut dikeringkan pada suhu $60^{\circ} \mathrm{C}$ selama 1 hari.

\section{Uji swelling ratio}

SRF kering ditimbang (Wo) lalu direndam dalam $30 \mathrm{~mL}$ aquadest. Setelah beberapa saat, biohidrogel diangkat dan permukaannya dikeringkan dengan menggunakan kertas hisap. Kemudian biohidrogel tersebut ditimbang kembali berdasarkan rentang waktu yang telah ditentukan tiap 10 menit selama 120 menit massa biohidrogel setelah waktu pengangkatan biohidrogel (Ws).

\section{Uji Wet Retention}

SRF (Slow Release Fertilizer) kering dibenamkan di dalam tanah kering yang ditempatkan dalam cangkir (A). Sejumlah tanah kering lain tanpa biohidrogel SRF ditempatkan dalam cangkir (B). Kemudian ditimbang massa tanah (blanko) dan massa tanah plus biohidrogel (W). Dilakukan penimbangan kembali massa tanah (blanko) dan massa tanah plus biohidrogel setelah penambahan air suling dengan penambahan air suling sebanyak $20 \mathrm{~mL}$. Kedua cangkir tersebut disimpan pada kondisi suhu kamar yang sama dan ditimbang setiap hari (Wt) selama 17 hari.

\section{Uji Pelepasan dalam media air}

Sebanyak 1 gram SRF direndam di dalam air kemudian diukur kadar nitrogen yang terlepas di dalam air. Perubahan kadar nitrogen dalam larutan diamati setelah 2, 7, 12, 17 dan 22 hari. serta hari ke-n $\urcorner$ pada saat urea 90\% hilang, masing-masing diuji kadar ureanya menggunakan spektrofotometer UV vis.

\section{Uji Pelepasan dalam media tanah}

Tanah berpasir yang kering disaring menjadi partikel berukuran kurang dari $2 \mathrm{~mm}$. SRF sebanyak 1 gram dicampur dengan 10 gram tanah tersebut. Campuran dimasukkan ke dalam tabung berdiameter $5 \mathrm{~cm}$ untuk uji pelepasan urea. Air ditambahkan ke dalam tabung sebanyak $20 \mathrm{~mL}$. Larutan yang telah melewati tanah dalam tabung dikumpulkan setelah waktu 2, 7, 12, 17 dan 22 hari; sampai hari ke-n pada saat urea 100 hilang, masing-masing diuji kadar ureanya menggunakan spektrofotometer UV vis. 


\section{Penentuan konstanta pelepasan pupuk urea}

Pelepasan Nitrogen dalam pupuk urea dianalisa menggunakan 3 model kinetika yaitu higuchi, korsmeyerpeppas dan orde 1. Data percobaan dimasukkan ke dalam masing-masing persamaan tersebut kemudian dicari nilai $\mathrm{k}$ (konstanta) pelepasan nitrogen dengan regresi linier.

All material on all pages should fit within an area of A4 $(21 \times 29.7 \mathrm{~cm}), 2.8 \mathrm{~cm}$ from the top of the page and ending with $2.4 \mathrm{~cm}$ from the bottom. The left and right margins should both be $2.4 \mathrm{~cm}$.

\section{Hasil dan Pembahasan}

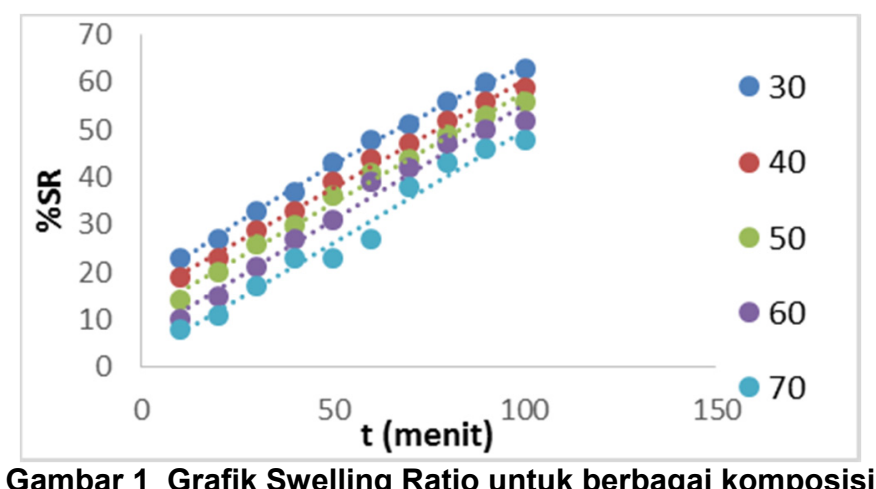

1. Uji Swelling Ratio

Swelling ratio merupakan kemampuan suatu material untuk menahan air dalam material tersebut. Dari gambar 1 menunjukan \%SR berbanding lurus dengan waktu, terlihat pada massa komposisi urea 30\% memiliki nilai swelling ratio paling tinggi dan komposisi urea $70 \%$ memiliki swelling ratio paling rendah. Pada komposisi urea 30\%, material tersebut memiliki pelapis paling tebal dan komposisi urea $70 \%$ memiliki pelapis yang paling tipis. Hal ini menunjukkan semakin tebal lapisan suatu material akan menyebabkan material tersebut semakin baik menahan air didalamnya

2. Uji Water Retention

Tabel 1 Data Wet Retentio (\%)

\begin{tabular}{llllll}
\hline Waktu & \multicolumn{6}{l}{ Wet Retention $(\%)$} \\
$(\mathrm{t})$ & $30 \%$ & $40 \%$ & $50 \%$ & $60 \%$ & $70 \%$ \\
\hline 2 & 79 & 80 & 82 & 86 & 89 \\
7 & 41 & 46 & 43 & 47 & 50 \\
12 & 12 & 18 & 23 & 26 & 27 \\
17 & 0 & 4 & 5 & 4 & 6 \\
\hline
\end{tabular}

Uji water retention (WR) dilakukan untuk mengetahui kemampuan pupuk untuk mempertahankan kelembaban tanah. Pada tabel 2 dapat dilihat untuk semua pupuk kemampuan WR mengalami penurunan dengan semakin bertambahnya waktu. Penurunan ini diakibatkan oleh penguapan akibat lingkungan sekitar tanah (suhu dan kelembaban).

3. Uji Pelepasan Slow Release Urea dalam Media Air dan Tanah 
Tabel 2 Model kinetika Pelepasan Pupuk

\begin{tabular}{|c|c|c|c|c|c|}
\hline \multirow[b]{2}{*}{$\begin{array}{l}\text { Kon } \\
\text { sen } \\
\text { trasi }\end{array}$} & \multirow[b]{2}{*}{$\begin{array}{l}\text { Para } \\
\text { meter }\end{array}$} & \multicolumn{4}{|c|}{ Model kinetika pelepasan pupuk } \\
\hline & & Orde 0 & $\begin{array}{l}\text { Orde } \\
1\end{array}$ & $\begin{array}{l}\text { higuc } \\
\text { hi }\end{array}$ & $\begin{array}{l}\text { Korsme } \\
\text { yer } \\
\text { Peppas }\end{array}$ \\
\hline \multicolumn{6}{|c|}{ Pelepasan dalam Media Air } \\
\hline & $\mathrm{R}$ & $-0,34$ & $-1,44$ & 0,855 & 0,990 \\
\hline \multirow[t]{3}{*}{30} & $\mathrm{k}$ & 0,049 & $-0,015$ & 0,205 & 0,318 \\
\hline & $\mathrm{n}$ & & & & 0,336 \\
\hline & $\mathrm{R}$ & $-0,71$ & $-1,82$ & 0,784 & 0,992 \\
\hline \multirow[t]{2}{*}{40} & $\mathrm{~K}$ & 0,046 & $-0,019$ & 0,193 & 0,308 \\
\hline & $\begin{array}{l}N \\
R\end{array}$ & $-4,44$ & -1.92 & 0.784 & $\begin{array}{l}0,323 \\
0,959\end{array}$ \\
\hline \multirow[t]{3}{*}{50} & $\mathrm{~K}$ & 0,050 & $-0,013$ & 0,193 & 0,463 \\
\hline & $\mathrm{N}$ & & & & 0,207 \\
\hline & $\mathrm{R}$ & $-1,93$ & $-1,7$ & 0,430 & 0,961 \\
\hline \multirow[t]{2}{*}{60} & $\begin{array}{l}\mathrm{K} \\
\mathrm{N}\end{array}$ & 0,048 & $-0,015$ & 0,206 & $\begin{array}{l}0,385 \\
0,266\end{array}$ \\
\hline & $\mathrm{R}$ & -186 & $-1,67$ & 0,443 & 0,969 \\
\hline \multirow[t]{2}{*}{70} & $\mathrm{~K}$ & 0,049 & $-0,014$ & 0,210 & 0,398 \\
\hline & $\mathrm{N}$ & & & & 0,359 \\
\hline \multicolumn{6}{|c|}{ Pelepasan dalam Media Tanah } \\
\hline & $\mathrm{R}$ & 0,946 & $-11,9$ & 0,956 & 0,973 \\
\hline \multirow[t]{3}{*}{30} & K & 0,009 & $-0,205$ & 0,050 & 0,047 \\
\hline & $\mathrm{N}$ & & & & 0,522 \\
\hline & $\mathrm{R}$ & 0,946 & $-8,88$ & 0,905 & 0,985 \\
\hline \multirow[t]{3}{*}{40} & $\mathrm{~K}$ & 0,014 & $-0,216$ & 0,045 & 0,030 \\
\hline & $\mathrm{N}$ & & & & 0,680 \\
\hline & $\mathrm{R}$ & 0,527 & $-12,1$ & 0,905 & 0,977 \\
\hline \multirow[t]{3}{*}{50} & $\mathrm{~K}$ & 0,020 & $-0,178$ & 0,045 & 0,070 \\
\hline & $\mathrm{N}$ & & & & 0,449 \\
\hline & $\mathrm{R}$ & 0,762 & $-12,0$ & 0,952 & 0,968 \\
\hline \multirow[t]{3}{*}{60} & $\mathrm{~K}$ & 0,018 & $-0,185$ & 0,057 & 0,054 \\
\hline & $\mathrm{N}$ & & & & 0,517 \\
\hline & $\mathrm{R}$ & 0,598 & $-10,9$ & 0,980 & 0,984 \\
\hline \multirow[t]{2}{*}{70} & $\mathrm{~K}$ & 0,019 & $-0,191$ & 0,060 & 0,064 \\
\hline & $\mathrm{N}$ & & & & 0,472 \\
\hline
\end{tabular}

Profil pelepasan pupuk dianalisis dengan mencocokkanya terhadap persamaan kinetika orde 0 , orde 1 , higuchi dan korsmeyer-peppas. Dari setiap persamaan kinetika yang dicocokkan didapat nilai konstanta pelepasan pupuk (k), koefisien korelasi (R), dan nilai difusi (n) untuk persamaan korsmeyer-peppas. Berdasarkan data pada tabel 3 semua pelepasan mengikuti model kinetika Korsmeyer peppas.Analisis mekanisme pelepasan pada model kinetika korsmeyer-peppas ditinjau dengan memperhatikan nilai $\mathrm{n}$. Untuk nilai $\mathrm{n}<0,45$ pelepasan mengikuti mekanisme difusi fickian, sedangkan jika nilai $\mathrm{n}$ berada dalam rentang $0,45<\mathrm{n}<0,89$ pelepasan mengikuti mekanisme non-fickian.

Berdasarkan data pada tabel 3 untuk pelepasan dalam media air semuanya memiliki nilai $n<0,45$ yang berarti pelepasan tersebut mengikuti mekanisme fickian. Untuk pelepasan dalam media tanah sebagian besar memiliki nilai n diantara 0,45-0,89 yang berarti pelepasan pupuk tersebut mengikuti mekanisme non-fickian. Hanya untuk konsentrasi urea 30\% yang pelepasannya mengikuti mekanisme fickian, karena memiliki nilai $\mathrm{n}=0,449$.

\section{Kesimpulan}

Pelepasan pupuk urea dalam media air mengikuti persamaan KorsmeyerPeppas, dengan kpp sebagai berikut : $30 \%=0,318,40 \%=0,308,50 \% 0,463,60 \%=0,385,70 \%=0,398$. Pelepasan pupuk urea dalam media air mengikuti mekanisme fickian, dengan nilai n sebagai berikut : $30 \%=0,336,40 \%=0,325$, $50 \%=0,207,60 \%=266,70 \%=0,259$ Pelepasan pupuk urea dalam media tanah untuk semua konsentrasi 
urea megikuti persamaan Korsmeyer-Peppas, dengan nila kkp sebagai berikut : $30 \%=0,047,40 \%=0,030$, $50 \%=0,070,60 \%=0,054,70 \%=0,064$

Pelepasan pupuk urea dalam media tanah untuk konsentrasi urea 50\% megikuti mekanisme fickian dengan nilai $\mathrm{n}=0,449$, sedangkan untuk konsentrasi urea $30 \%, 40 \%, 60 \%, 70 \%$, mengikuti mekanisme nonfickian dengan nila n sebagai berikut : $30 \%=0,522,40 \%=0,680,60 \%=0,517,70 \%=0,472$

\section{Daftar Pustaka}

Cai et.al. (2006) Genomewide Screen Reveals a Wide Regulatory Network for Di/Tripeptide Utilization in Saccharomy cescerevisia Genetics 172(3) : 1459-76

Diwani et. al., 2013, Recovery of ammonia nitrogen from industrial wastewater treatment as struvite slow releasing fertilizer

Dhillon GS, et al. (2012) Green approach for nanoparticle biosynthesis by fungi: current trends and applications. Crit Rev Biotechnol 32(1):49-73

Jamnongkan and Kaewpirom, 2010, Potassium Release Kinetics and Water Retention of ControlledRelease Fertilizers Based on Chitosan Hydrogels

Muhammad et al, 2013, Influence of Organic Mulches on Growth and Yield Components of Pea's Cultivars, Khyber Pakhtunkhwa Agricultural University Peshawar, Pakistan.

Peppas, N. A., 1985, Analysis of Fickian and non-Fickian drug release from polymers

Sagheer, J., Muslim, S., 1996, Thermal and Mechanical Properties of Chitosan/Hybrid Composites, Department of Chemistry, Kuwait University, Faculty of Science

Teli, M. D., Javed Sheikh, and Pragati Shastrakar, 2012, Exploratory Investigation of Chitosan as Mordant for Eco-Friendly Antibacterial Printing of Cotton with Natural Dyes, Department of Fibers and Textile Processing Technology, Institute of Chemical Technology, India

Wu, C. A., et. Al., 2008, Microarray-based analysis of stress-regulated micro RNAs in Arabidopsis thaliana 